\title{
Experimental Room Fire Studies with Perforated Suspended Ceiling
}

\author{
FIONA S.C. TSUI ${ }^{1}$, W.K. CHOW ${ }^{1}$, N.K. FONG ${ }^{1}$, Y. GAO ${ }^{2}$, H. DONG ${ }^{2}$, and G.W. ZOU ${ }^{2}$ \\ ${ }^{1}$ Research Centre for Fire Engineering \\ Department of Building Services Engineering \\ Area of Strength: Fire Safety Engineering \\ The Hong Kong Polytechnic University, Hong Kong, China \\ ${ }^{2}$ Department of Building Engineering \\ Harbin Engineering University \\ Harbin, Heilongjiang, China
}

\begin{abstract}
Suspended false ceilings are commonly installed as a new interior design feature in modern buildings of the Far East. Different shapes, profiles, materials and installation methods were adopted. There are fire safety concerns on extending the activation time and disturbing the water spray pattern of sprinkler systems. Ceilings with timber products might also be ignited. It is necessary to study the differences in thermal environment of a fire in rooms with and without suspended ceiling features.

Full-scale burning tests on wood perforated ceilings were carried out to study the indoor temperature distributions in a room fire. Two small fire sources of $250 \mathrm{~kW}$ and $500 \mathrm{~kW}$ were set up in a room of size $3.6 \mathrm{~m}$ by $2.4 \mathrm{~m}$ and height $4.5 \mathrm{~m}$. Air temperatures at both the solid ceiling level and the perforated false ceiling level were measured. Effect of perforated ceiling on actuation of liquid-in-bulb sprinkler heads was also studied. The time to actuate the sprinkler heads mounted at the solid ceiling level and the perforated ceiling level were measured.

Tests results indicated that the perforated ceiling would affect the room fire behavior. Both the ceiling layer temperature and the maximum room temperature are affected. Effect on the room air temperature depends on the configuration of the perforated ceiling such as the degree of perforation, materials and mounting height. The orders of magnitude of the fire sources used in these tests would represent the room temperature distribution in the early stage of an accidental fire. Information in the early stage of a fire is useful to study its effect on thermal activation of fire service installations. For a larger fire size, the combustible cell ceiling was ignited and burned. Further tests on the effect of heat contribution from a combustible cell ceiling are recommended.
\end{abstract}

KEYWORDS: suspended false ceiling, temperature, perforated ceiling, sprinklers.

\section{INTRODUCTION}

Suspended false ceilings are commonly found in modern buildings in the Far East. Conventionally, they are made of gypsum material and are usually flat, continuous, square or rectangular in shape in standardized dimensions. False ceilings are usually regarded as an interior lining for decorative and finishing purposes in the built environment. The potential fire hazards are of concern. Ignitability (e.g. AS/NZS 1530.3 [1]), combustibility (e.g. AS 1530.2 [2]), spread of flame (e.g. BS 476 Part 7 [3], BS EN 13501-1:2002 [4]), extent of contribution to fire growth and spread from the lining materials (e.g. ISO 9705 [5], NFPA 286 [6]) are specified in some overseas fire codes [7-9]. However, only spread of flame (e.g. BS 476 Part 7 [3], BS EN 13501-1:2002 [4]) and non-combustible construction materials are specified in the Hong Kong building fire regulations $[10,11]$. Appropriate fire tests [12] are required to evaluate the fire behavior of the materials. These tests vary internationally [13] from small or bench-scale tests to full-scale room fire tests [14-16].

In the past few decades, a wide variety of suspended ceilings with various shapes, profiles, materials and installation methods has evolved to suit the ever-changing interior design trend, to match any indoor design theme and to meet the community's increasingly desired aesthetic expectations. Perforated suspended ceilings as in Fig. 1 are now commonly used to give an open visual impression and/or to allow proper functioning of smoke control systems [17]. Perforated suspended ceilings vary in a wide range of shapes and profiles such as square, curved, parallel strip, panel or wire mesh types. To suit the design needs, materials also vary greatly including aluminum, paper, wood, steel and fabric.

The presence of perforated ceiling leads to various questions in relation to the effect on fire service installations as well as fire growth contribution inside the rooms. Very limited studies $[18,19]$ concerning the effect of 
perforated ceiling such as on sprinkler actuation and smoke filling process are reported in the literature. As realized, it is not simple or easy, without sufficient full-scale experimental tests, to quantify those effects so as to prescribe the wide range of design configurations of perforated ceilings to minimize the effects. Sprinkler design standards (e.g. BS EN 12845 [20]) have specified that the suspended ceiling configuration should be regular in shape having more than $70 \%$ free area and have the minimum opening dimension more than $0.025 \mathrm{~m}$ and installed more than $0.8 \mathrm{~m}$ from the ceiling soffit, to take into account the effect of open cell ceilings on efficient fire control by sprinklers. On the other hand, the use of materials is controlled by international building codes [7-10], focusing on flat continuous false ceilings rather than open type cell ceilings. In Hong Kong, there is no specific clause in the building fire safety codes [10,11,21,22] to inhibit interior decoration within escape staircases except that the escape staircases should be constructed by non-combustible materials [11] and any decorative linings inside should be of BS 476 Part 7 [3] Class 1 or 2 rate of surface spread of flame. For most accommodation uses, materials for interior decoration, including false ceilings, have not been restricted except that for some premises subject to licenses including restaurants, catering areas, karaoke establishments and places of public entertainment. Different designs of interior ceilings have evolved quickly as a modern design trend. It is necessary to understand the effect of perforated ceilings on building fires and possible impact on the functioning of fire service installations, particularly the sprinkler system.

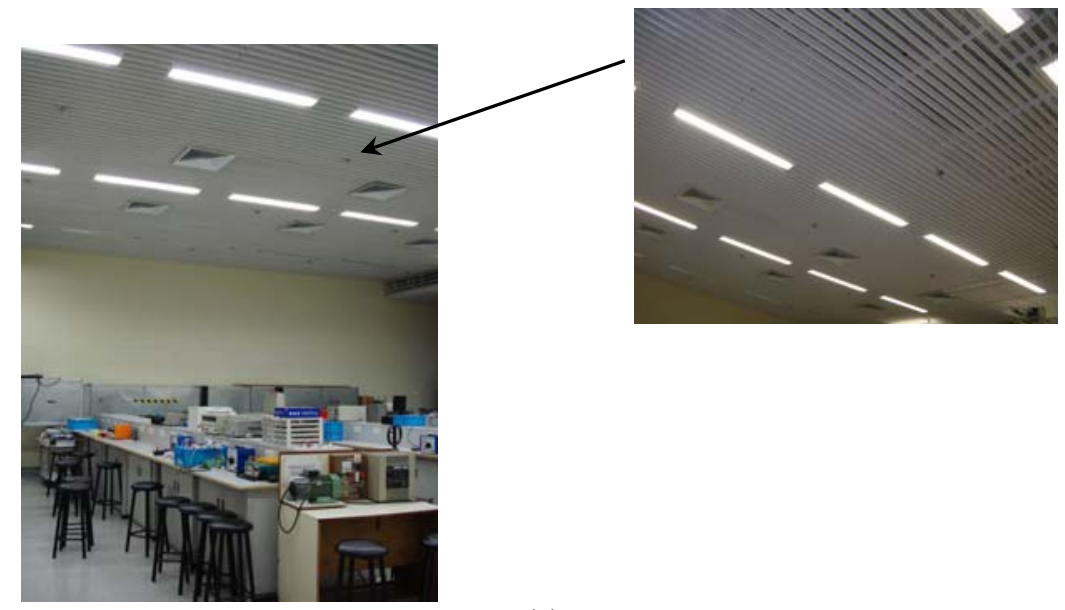

(a)

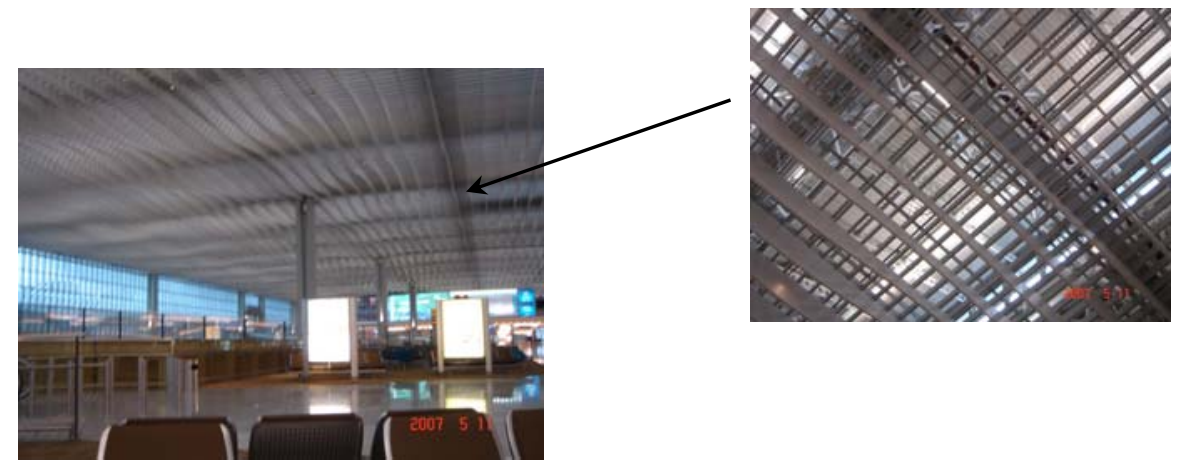

(b)

Fig. 1. Examples of perforated ceilings: (a) a laboratory; (b) an airport terminal.

\section{FULL-SCALE BURNING TESTS}

Full-scale burning tests were carried out in a room of length $3.6 \mathrm{~m}$, width $2.4 \mathrm{~m}$ and height $4.5 \mathrm{~m}$. Air temperature distributions inside the room were measured with and without an open cell false ceiling for two fire sizes of $250 \mathrm{~kW}$ and $500 \mathrm{~kW}$. The open cell ceiling is made of bare wood located $3 \mathrm{~m}$ above floor and hence, a $1.5 \mathrm{~m}$ ceiling void as shown in Fig. 2.

Common liquid-in-bulb sprinkler heads rated at $68^{\circ} \mathrm{C}$ were installed inside the room. Two layers of sprinkler, a total of 4 sprinkler heads, were installed in the open cell false ceiling. Configuration of the experimental 
set-up is also shown in Fig. 2. Annotations T1, T2, T3 and T4 in Fig. 2b and Fig. 3 indicate the sprinklers locations. Activation times of the two layers of sprinkler heads were recorded through observation of water discharge.

Gas temperatures at various heights inside the tested room (Thermocouples M1 to M9), at the doorway (Thermocouples D1 to D4) and adjacent to the sprinklers (Thermocouples T1 to T4) were measured using K-Type stainless steel sheathed thermocouples with $3 \mathrm{~mm}$ diameter. Sectional and plan views for the locations of thermocouples are shown in Fig. 3.

Two gasoline pool fires of diameters $460 \mathrm{~mm}$ and $500 \mathrm{~mm}$ were first tested to quantify the heat output. The heat release rate for these pool fires, $8 \mathrm{~L}$ gasoline in $460 \mathrm{~mm}$ diameter pool and $5 \mathrm{~L}$ gasoline in $500 \mathrm{~mm}$ diameter pool, measured separately in a room calorimeter [5] are shown in Figs. 4a and $4 \mathrm{~b}$. The $460 \mathrm{~mm}$ diameter fire pool produced a fairly constant heat release rate of $250 \mathrm{~kW}$ at $200 \mathrm{~s}$ after ignition. The $500 \mathrm{~mm}$ produced an average peak heat release rate of $500 \mathrm{~kW}$. Three types of fire source were used (i) $250 \mathrm{~kW}$ test fire, a $460 \mathrm{~mm}$ diameter pan with $2 \mathrm{~L}$ gasoline; (ii) $250 \mathrm{~kW}$ test fire, a $460 \mathrm{~mm}$ diameter pan with $4 \mathrm{~L}$ gasoline and; (iii) $500 \mathrm{~kW}$ test fire, a $500 \mathrm{~mm}$ diameter pan with $5 \mathrm{~L}$ gasoline. Limiting the gasoline quantity from $8 \mathrm{~L}$ initially to $4 \mathrm{~L}$ for the $250 \mathrm{~kW}$ test fire with a $460 \mathrm{~mm}$ diameter pan would give a burning duration similar to that of $500 \mathrm{~mm}$ diameter pool fire with $5 \mathrm{~L}$ gasoline.

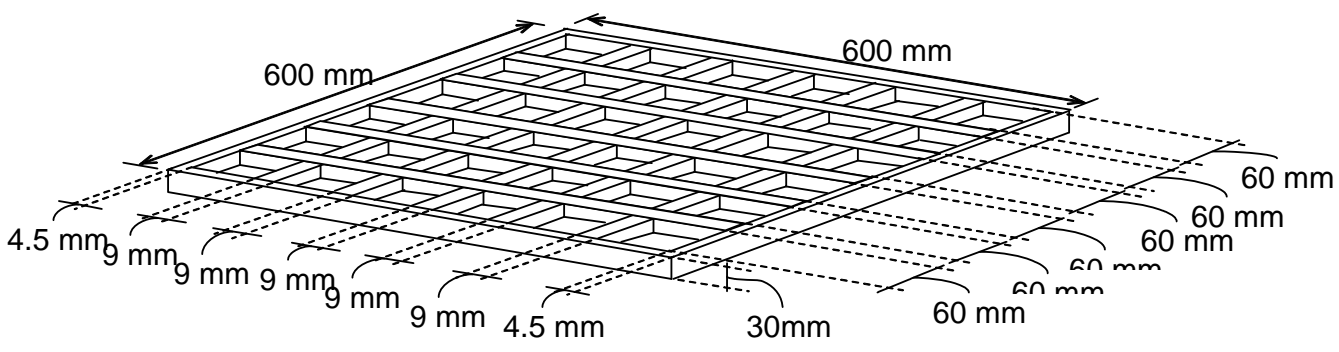

(a)

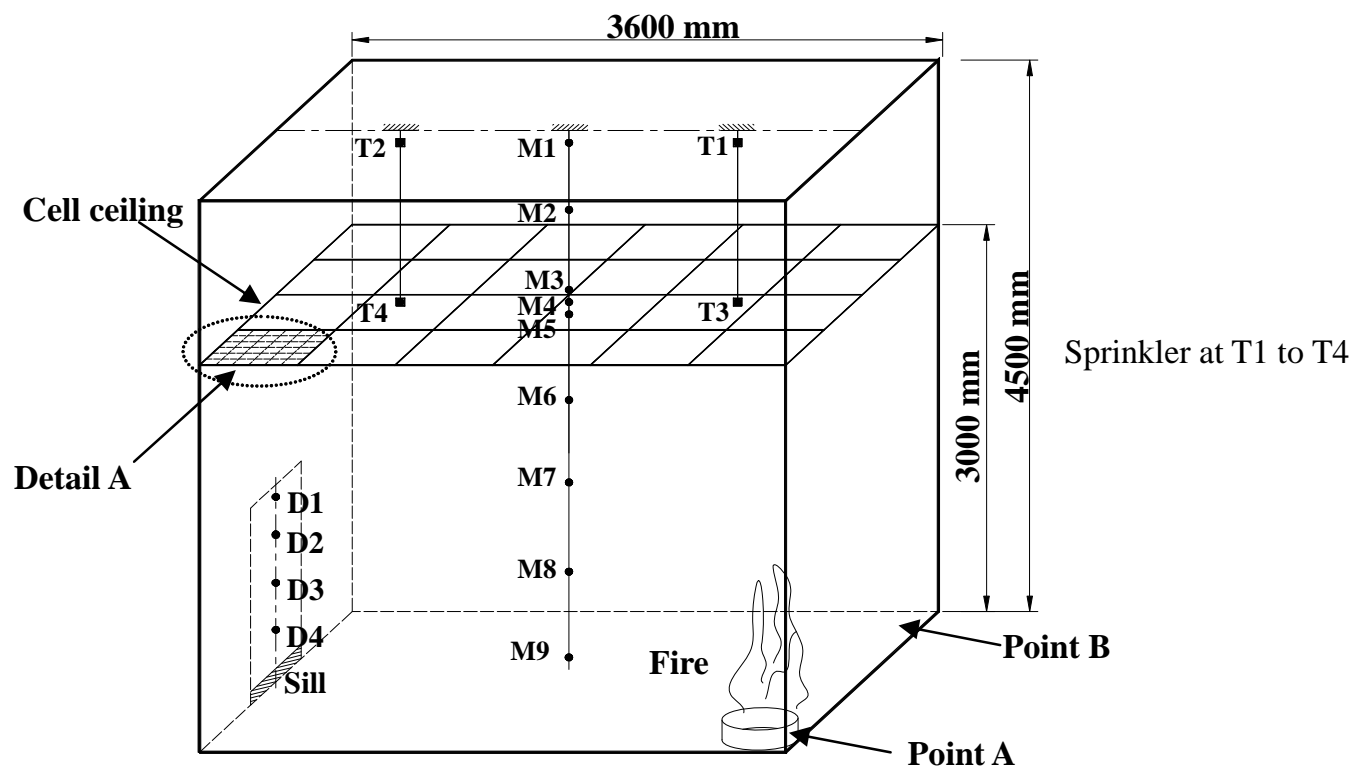

(b)

Fig. 2. Experimental rig: (a) perforated ceiling (Detail A); (b) test room and open cell ceiling. 


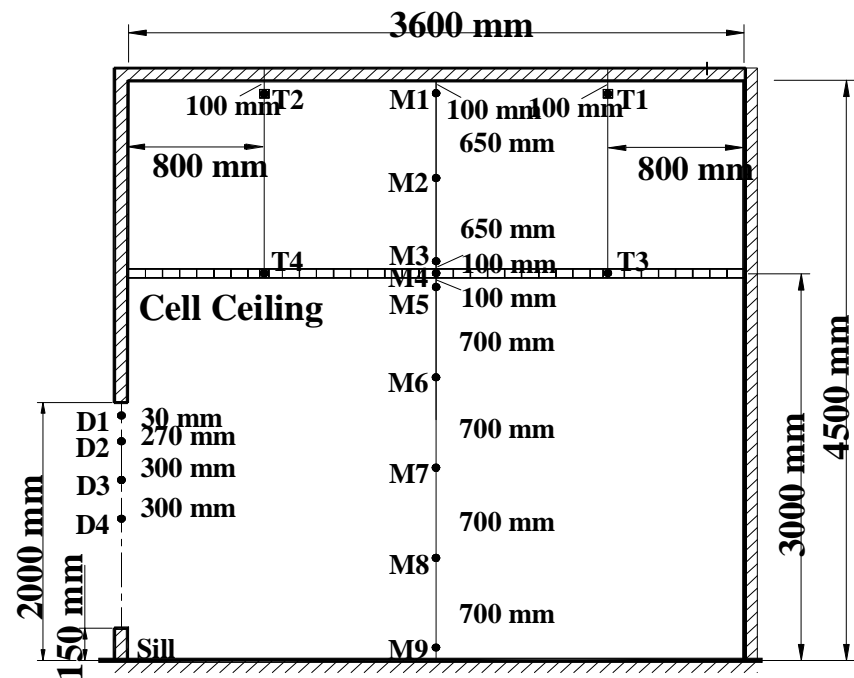

- Thermocouple with sprinkler at T1 to T4

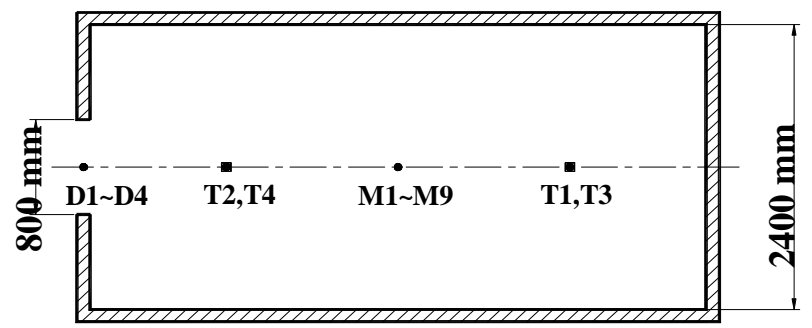

Fig. 3. Locations of thermocouples.

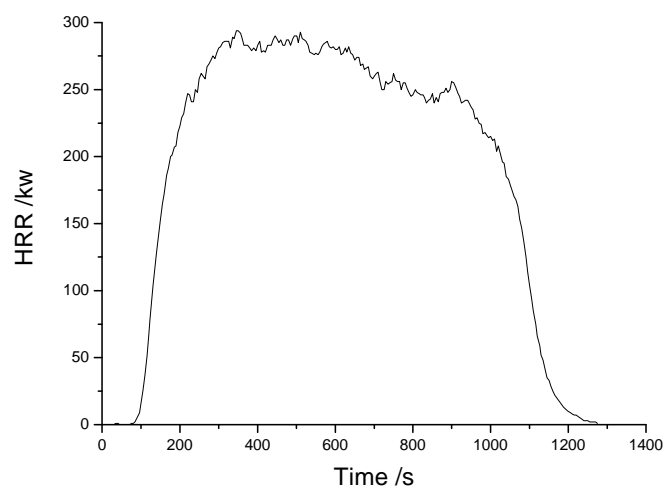

(a)

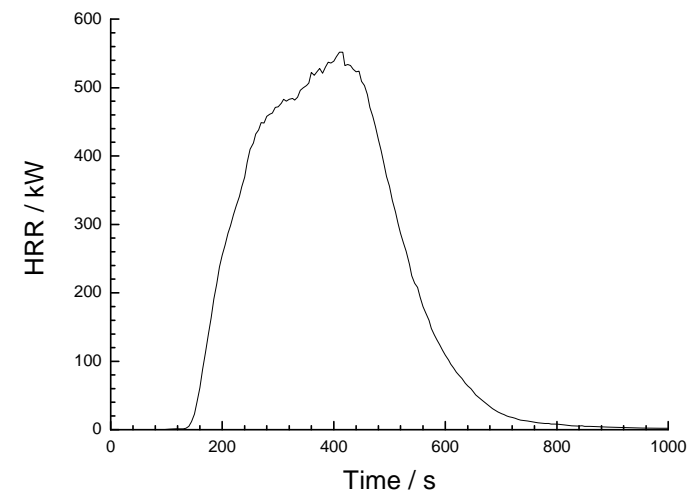

(b)

Fig. 4. Heat release rate of the fires: (a) $8 \mathrm{~L}$ of gasoline in $460 \mathrm{~mm}$ diameter pool; (b) $5 \mathrm{~L}$ of gasoline in $500 \mathrm{~mm}$ diameter pool.

A total of 7 fire tests with and without the perforated ceiling were carried out. Tests PC1 to PC4 were with perforated ceiling and Tests NP1 to NP3 were without the perforated ceiling.

- Test PC1:

Perforated ceiling - presence; test fire $-250 \mathrm{~kW}$ by using $2 \mathrm{~L}$ of gasoline with a $460 \mathrm{~mm}$ diameter pool; test fire location - Point A in Fig. 2.

- Test PC2:

Perforated ceiling - presence; test fire $-250 \mathrm{~kW}$ by using $4 \mathrm{~L}$ gasoline with a $460 \mathrm{~mm}$ diameter pool; test fire location - Point A in Fig. 2. Same test conditions as for Test PC1 except that a longer burning duration was set with double quantity of fuel, $4 \mathrm{~L}$ of gasoline. 
Table 1. Maximum air temperatures and time to peak values measured.

\begin{tabular}{|c|c|c|c|c|c|c|c|c|c|c|c|c|c|c|c|}
\hline \multicolumn{2}{|c|}{ Tests } & \multicolumn{2}{|c|}{ PC1 } & \multicolumn{2}{|c|}{ PC2 } & \multicolumn{2}{|c|}{ PC3 } & \multicolumn{2}{|c|}{ PC4 } & \multicolumn{2}{|c|}{ NP1 } & \multicolumn{2}{|c|}{ NP2 } & \multicolumn{2}{|c|}{ NP3 } \\
\hline \multicolumn{2}{|c|}{ TCs } & \begin{tabular}{|c} 
Time \\
to \\
peak \\
(s)
\end{tabular} & $\begin{array}{c}\text { Peak } \\
\text { temp. } \\
\left({ }^{\circ} \mathrm{C}\right)\end{array}$ & $\begin{array}{c}\text { Time } \\
\text { to } \\
\text { peak } \\
\text { (s) }\end{array}$ & \begin{tabular}{|c} 
Peak \\
temp. \\
$\left({ }^{\circ} \mathrm{C}\right)$
\end{tabular} & $\begin{array}{c}\text { Time } \\
\text { to } \\
\text { peak } \\
\text { (s) }\end{array}$ & \begin{tabular}{|c} 
Peak \\
temp. \\
$\left({ }^{\circ} \mathrm{C}\right)$
\end{tabular} & $\begin{array}{c}\text { Time } \\
\text { to } \\
\text { peak } \\
\text { (s) }\end{array}$ & $\begin{array}{c}\text { Peak } \\
\text { temp. } \\
\left({ }^{\circ} \mathrm{C}\right)\end{array}$ & $\begin{array}{c}\text { Time } \\
\text { to } \\
\text { peak } \\
\text { (s) }\end{array}$ & $\begin{array}{c}\text { Peak } \\
\text { temp. } \\
\left({ }^{\circ} \mathrm{C}\right)\end{array}$ & $\begin{array}{c}\text { Time } \\
\text { to } \\
\text { peak } \\
\text { (s) }\end{array}$ & $\begin{array}{c}\text { Peak } \\
\text { temp. } \\
\left({ }^{\circ} \mathrm{C}\right)\end{array}$ & \begin{tabular}{|c} 
Time \\
to \\
peak \\
(s)
\end{tabular} & $\begin{array}{l}\text { Peak } \\
\text { temp. } \\
\left({ }^{\circ} \mathrm{C}\right)\end{array}$ \\
\hline \multirow{9}{*}{ 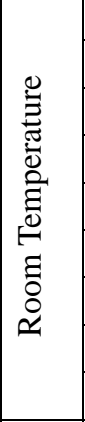 } & M1 & 233 & 130 & 210 & 135 & 375 & 240 & 370 & 255 & 280 & 147 & 119 & 276 & 210 & 130 \\
\hline & M2 & 248 & 100 & 210 & 108 & 395 & 175 & 380 & 175 & 240 & 128 & $214^{\mathrm{a}}$ & 225 & 240 & 118 \\
\hline & M3 & 100 & 63 & 270 & 75 & 345 & 80 & 240 & 80 & 200 & 93 & 99 & 165 & 210 & 107 \\
\hline & M4 & 250 & 39 & 290 & 53 & 395 & 65 & 480 & 78 & 220 & 93 & 129 & 165 & 210 & 102 \\
\hline & M5 & 233 & 60 & 280 & 63 & 365 & 75 & 350 & 94 & 220 & 101 & 129 & 170 & 165 & 102 \\
\hline & M6 & 271 & 85 & 310 & 97 & 415 & 135 & 410 & 138 & 380 & 115 & 219 & 190 & 260 & 117 \\
\hline & M7 & 248 & 70 & 670 & 74 & 435 & 78 & 490 & 83 & 590 & 82 & 204 & 100 & 255 & 80 \\
\hline & M8 & 271 & 48 & 630 & 57 & 425 & 68 & 400 & 73 & 570 & 54 & 179 & 70 & 270 & 52 \\
\hline & M9 & 250 & 39 & 660 & 39 & 415 & 48 & 380 & 48 & 580 & 38 & 209 & 40 & 250 & 35 \\
\hline \multirow{4}{*}{ : } & $\mathrm{T} 1$ & 163 & 125 & 210 & 138 & 375 & 255 & 382 & 223 & 230 & 163 & 99 & 327 & 150 & 150 \\
\hline & $\mathrm{T} 2$ & 286 & 90 & 620 & 107 & 415 & 175 & 398 & 170 & 430 & 112 & 279 & 202 & 270 & 95 \\
\hline & T3 & 161 & 58 & 210 & 65 & 375 & 80 & 390 & 93 & 180 & 90 & 119 & 167 & 150 & 95 \\
\hline & $\mathrm{T} 4$ & Fail & Fail & Fail & Fail & 395 & 70 & 400 & 82 & 290 & 82 & 199 & 167 & 150 & 95 \\
\hline
\end{tabular}

${ }^{\mathrm{a}}$ Time to reach the first maximum temperature $215^{\circ} \mathrm{C}$ is $119 \mathrm{~s}$.

Table 2. Times to actuate sprinkler heads.

\begin{tabular}{|c|c|c|c|c|c|c|}
\hline \multirow{2}{*}{ Test } & \multicolumn{4}{|c|}{ Times to actuate sprinkler heads (s) } & \multicolumn{2}{|c|}{ Cell ceiling } \\
\hline & T1 & T2 & T3 & T4 & Ignition occurred & At time (s) \\
\hline PC1 & 71 & 134 & Not burst & Not burst & No & - \\
\hline PC2 & \multicolumn{4}{|c|}{ Observation unsuccessful } & No & - \\
\hline PC3 & \multicolumn{4}{|c|}{ Observation unsuccessful } & Yes & 171 \\
\hline PC4 & \multicolumn{4}{|c|}{ Observation unsuccessful } & Yes & Unknown \\
\hline NP1 & \multirow{2}{*}{\multicolumn{2}{|c|}{$\begin{array}{l}\text { Observation unsuccessful } \\
\text { Observation unsuccessful }\end{array}$}} & 196 & 136 & No & - \\
\hline NP2 & & & 58 & 47 & No & - \\
\hline NP3 & \multicolumn{4}{|c|}{ Observation unsuccessful } & No & - \\
\hline
\end{tabular}

- Test PC3:

Perforated ceiling - presence; test fire $-500 \mathrm{~kW}$ by using $5 \mathrm{~L}$ gasoline with a $500 \mathrm{~mm}$ diameter pool; test fire location - Point A in Fig. 2. Same test conditions as for Test PC2 except that a larger fire size doubled to that in Test PC2 was set.

\section{- Test PC4}

Perforated ceiling - presence; test fire $-500 \mathrm{~kW}$ by using $5 \mathrm{~L}$ gasoline with a $500 \mathrm{~mm}$ diameter pool; test fire location - Point B in Fig. 2. Same test condition as for Test PC3 with the test fire located at the other corner of the room, which is to verify any difference in air temperature distribution with different location of fire source.

\section{- Test NP1:}

Perforated ceiling - absence; test fire $-250 \mathrm{~kW}$ by using $4 \mathrm{~L}$ gasoline with a $460 \mathrm{~mm}$ diameter pool; test fire location - Point A in Fig. 2. Same test conditions as for Test PC2 except that perforated ceiling was absence.

- Test NP2:

Perforated ceiling - absence; test fire $-500 \mathrm{~kW}$ by using $5 \mathrm{~L}$ gasoline with a $500 \mathrm{~mm}$ diameter pool; test fire location - Point A in Fig 2. Same test conditions as for Test NP1 except that a larger fire size doubled 
to that in Test NP1 was set.

\section{- Test NP3:}

Perforated ceiling - absence; test fire - $250 \mathrm{~kW}$ by using $2 \mathrm{~L}$ gasoline with a $460 \mathrm{~mm}$ diameter pool; test fire location - Point A in Fig. 2. Same test conditions as for Test NP1 except that a shorter burning duration was set with half quantity of fuel, 2 L of gasoline. Also same test conditions as for Test PC1 except that perforated ceiling was absence.

The measured room temperatures against time for Tests PC1, PC2, PC3, PC4, NP1, NP2 and NP3 are shown in Figs. 5 to 8 respectively. It is observed that air temperature inside the room increased quickly after ignition for all tests. A peak was reached and kept for a period of time, then dropped when the fuel was used up. The time to peak temperatures and maximum temperatures at the measured points for each test are summarized in Table 1 . The times to activate the sensing bulb of sprinklers for each test are shown in Table 2.

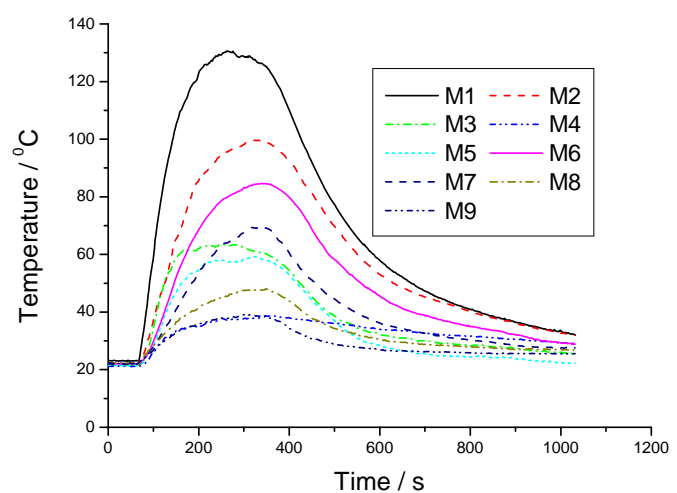

(a)

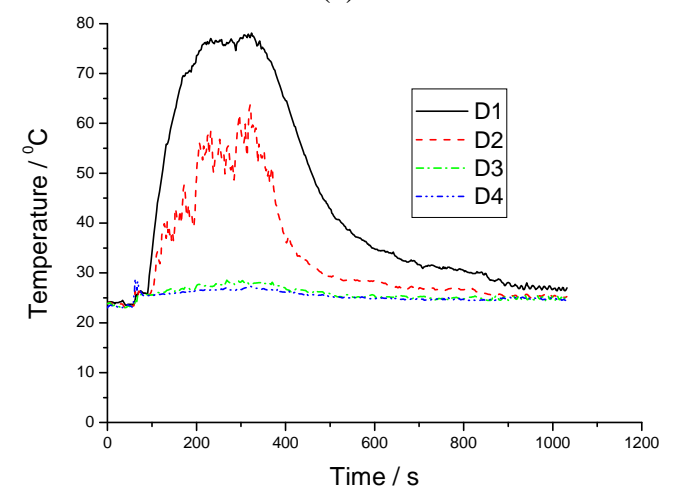

(c)

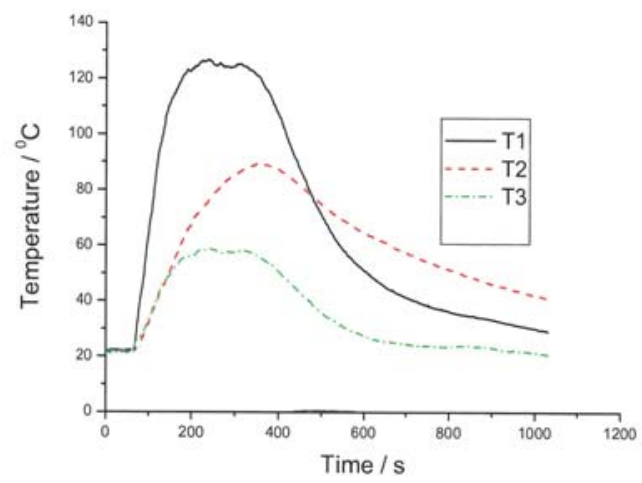

(e)

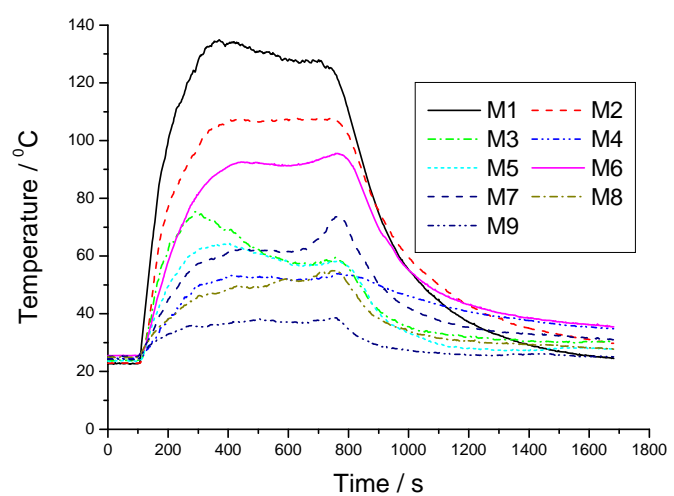

(b)

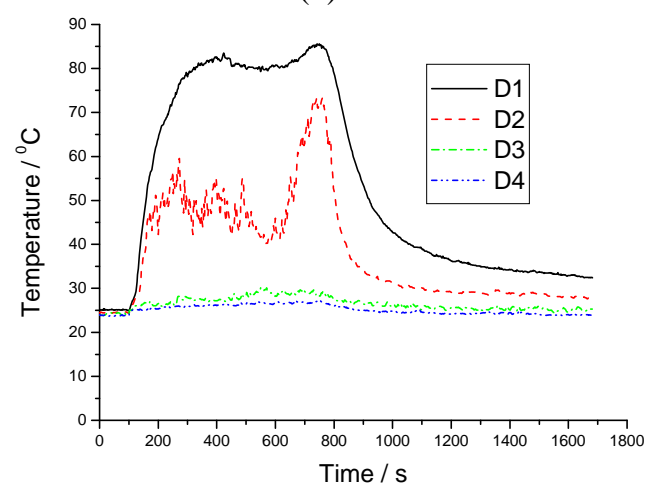

(d)

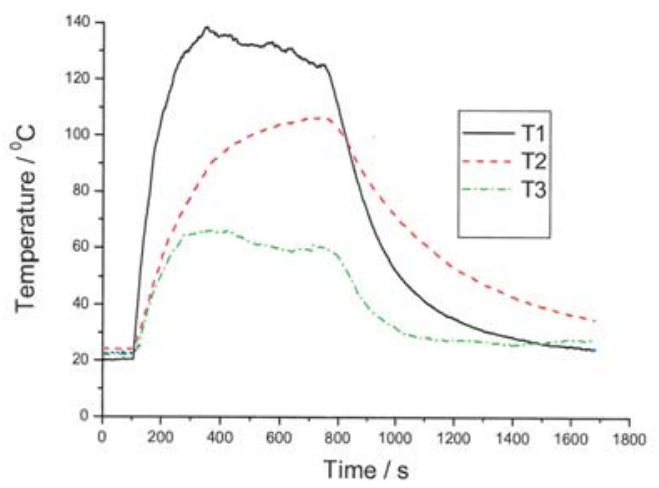

(f)

Fig. 5. Vertical room temperature distributions: (a) Test PC1; (b) Test PC2; Vertical doorway temperature distributions: (c) Test PC1; (d) Test PC2; Temperatures at two layers of sprinklers: (e) Test PC1; (f) Test PC2. 


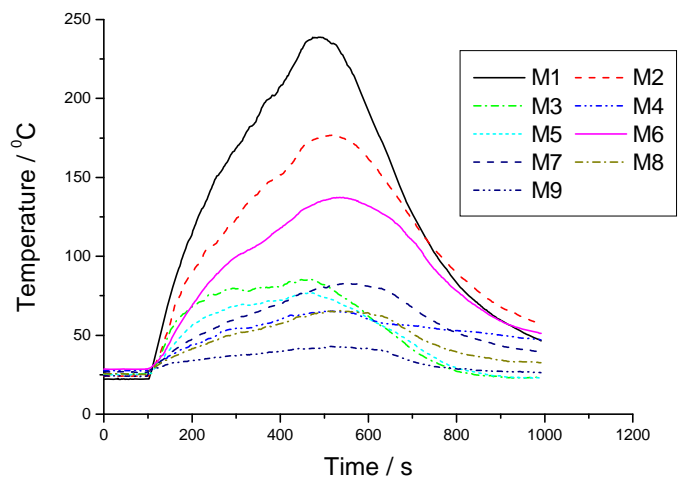

(a)

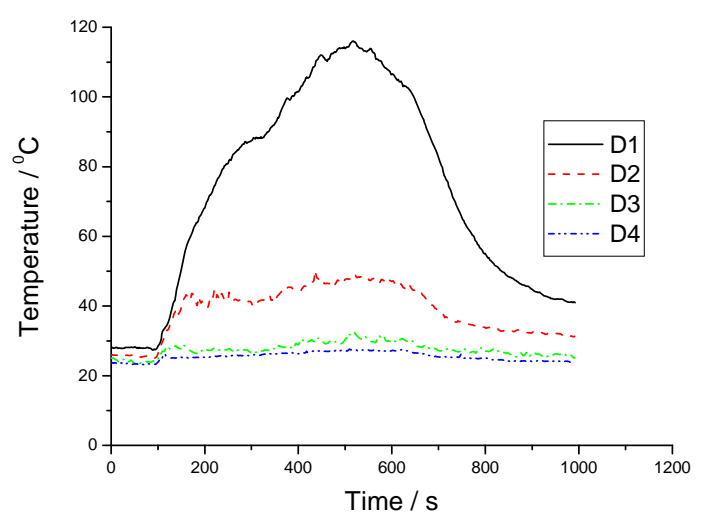

(c)

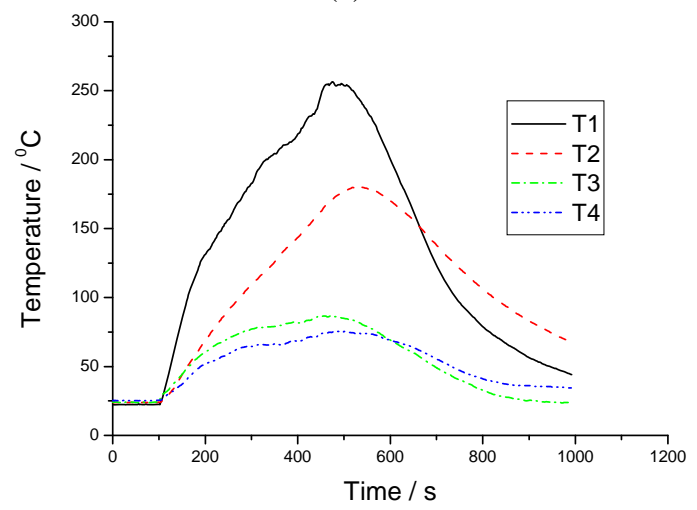

(e)

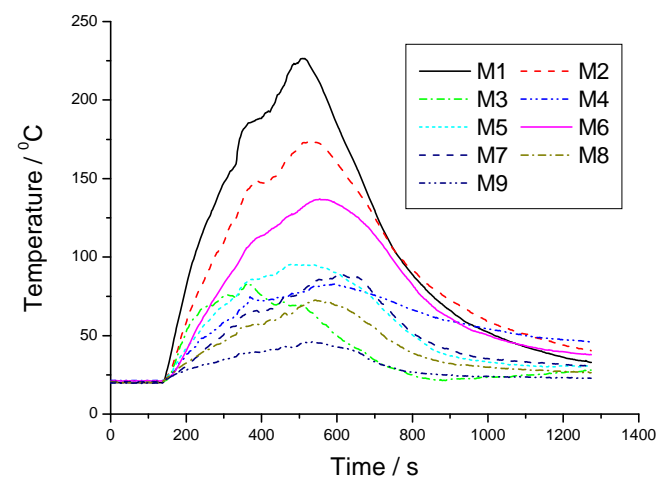

(b)

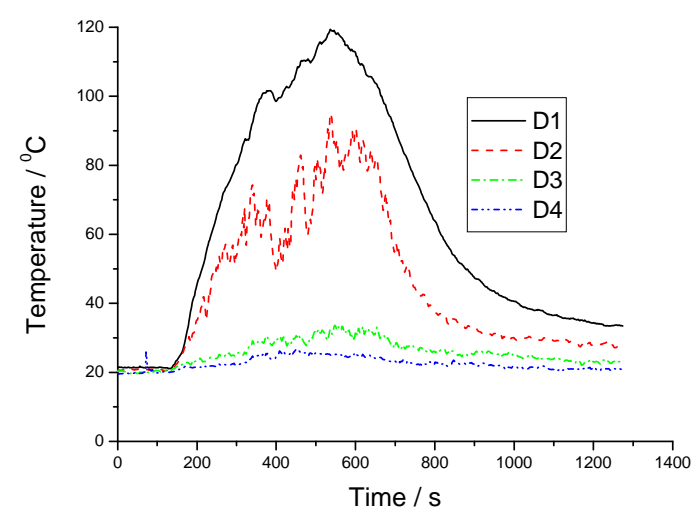

(d)

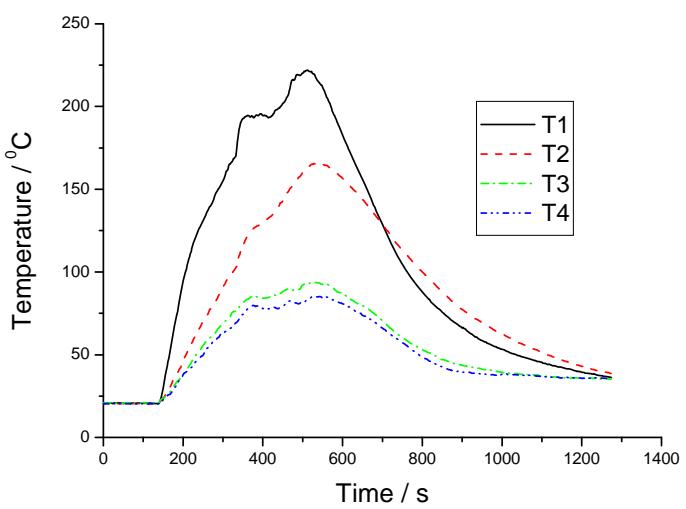

(f)

Fig. 6. Vertical room temperature distributions: (a) Test PC3; (b) Test PC4; Vertical doorway temperature distributions: (c) Test PC3; (d) Test PC4; Temperatures at two layers of sprinklers: (e) Test PC3; (f) Test PC4. 


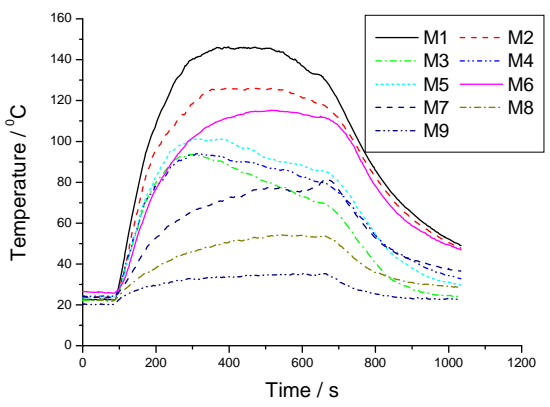

(a)

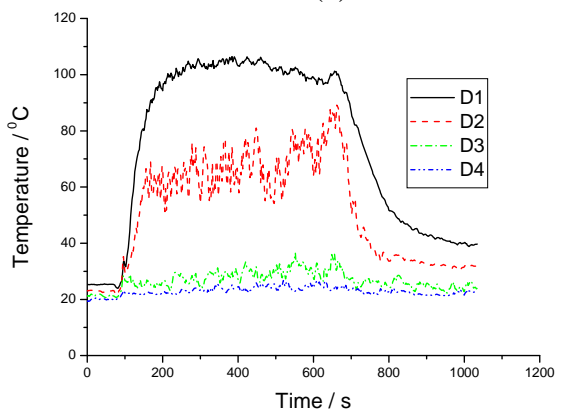

(c)

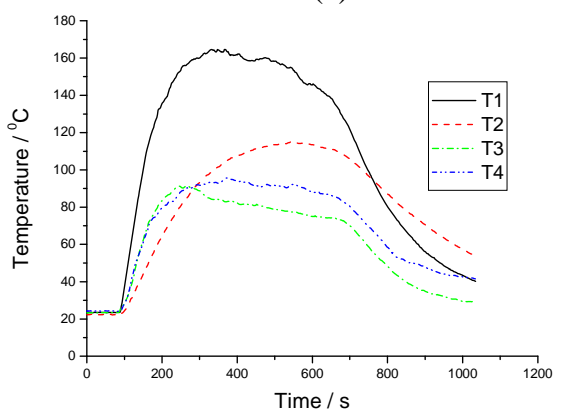

(e)

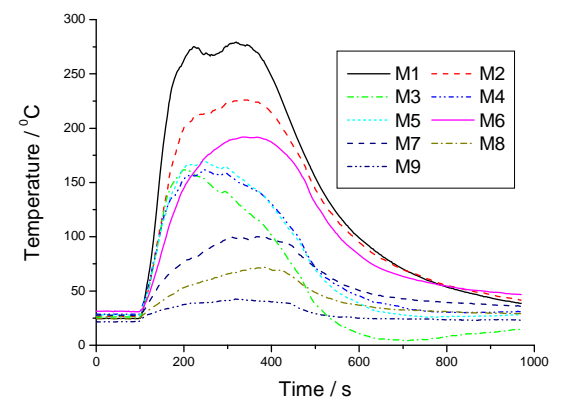

(b)

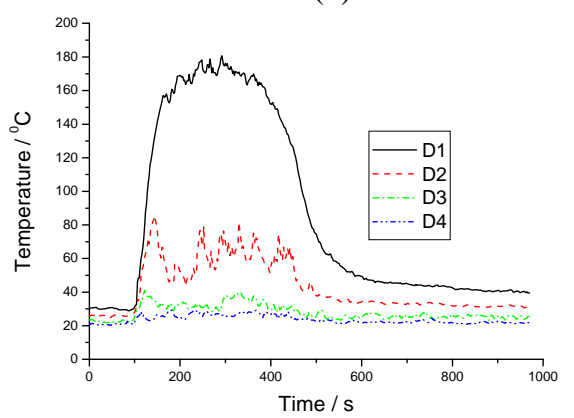

(d)

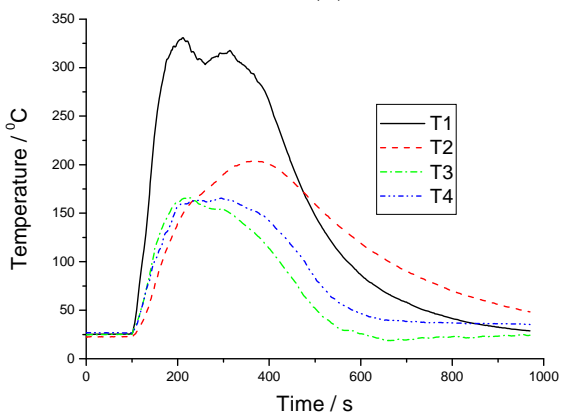

(f)

Fig. 7. Vertical room temperature distributions: (a) Test NP1; (b) Test NP2; Vertical doorway temperature distributions: (c) Test NP1; (d) Test NP2; Temperatures at two layers of sprinklers: (e) Test NP1; (f) Test NP2

\section{RESULTS WITH PERFORATED CEILING}

For Test PC1, the air temperature above the cell ceiling increased quickly and reached a maximum of $130{ }^{\circ} \mathrm{C}$ at $233 \mathrm{~s}$ after ignition, with $380 \mathrm{~s}$ burning duration. Air temperature at the cell ceiling level ( $3 \mathrm{~m}$ above floor) increased at a slightly slower rate than that above the cell ceiling, with a maximum of about $63^{\circ} \mathrm{C}$ which was found lower than the maximum temperature $85^{\circ} \mathrm{C}$ below the cell ceiling $(2.1 \mathrm{~m}$ above floor). Temperatures at sprinkler points T1, T2 and T3 reached a maximum of $125{ }^{\circ} \mathrm{C}$ at $163 \mathrm{~s}$ after ignition, $90{ }^{\circ} \mathrm{C}$ at $286 \mathrm{~s}$ after ignition, $58^{\circ} \mathrm{C}$ at $161 \mathrm{~s}$ after ignition, respectively. The thermocouple at sprinkler point T4 failed. Sensing bulbs of sprinklers at the solid ceiling burst at $97^{\circ} \mathrm{C}$ for point $\mathrm{T} 1$ and at $68{ }^{\circ} \mathrm{C}$ for point $\mathrm{T} 2$, whereas sensing bulbs of sprinklers at cell ceiling level did not burst.

For Test PC2, air temperature at above the cell ceiling reached a maximum of $135^{\circ} \mathrm{C}$ at $210 \mathrm{~s}$ after ignition and had a longer duration of peak as compared to Test PC 1 because of the longer burning duration of 739 s. Air temperature at the cell ceiling level increased at a slightly slower rate, with a maximum of $75^{\circ} \mathrm{C}$ which was lower than the maximum temperature $97^{\circ} \mathrm{C}$ below the cell ceiling $(2.1 \mathrm{~m}$ above floor). Temperatures at sprinkler point T1, T2 and T3 reached a maximum of $138^{\circ} \mathrm{C}$ at $210 \mathrm{~s}$ after ignition, $107^{\circ} \mathrm{C}$ at $620 \mathrm{~s}$ after ignition and $65^{\circ} \mathrm{C}$ at $210 \mathrm{~s}$ after ignition, respectively. The temperature at point T2 in fact increased rapidly at the first $290 \mathrm{~s}$ after ignition, reached $95^{\circ} \mathrm{C}$ and then increased gradually till its maximum of $107^{\circ} \mathrm{C}$. The thermocouple at sprinkler point T4 failed. The burst of sensing bulbs of sprinklers were not seen due to the noisy and invisible smoke-filled fire room environment. 


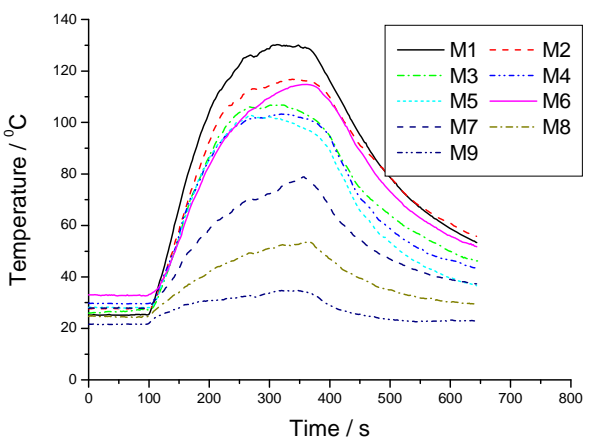

(a)

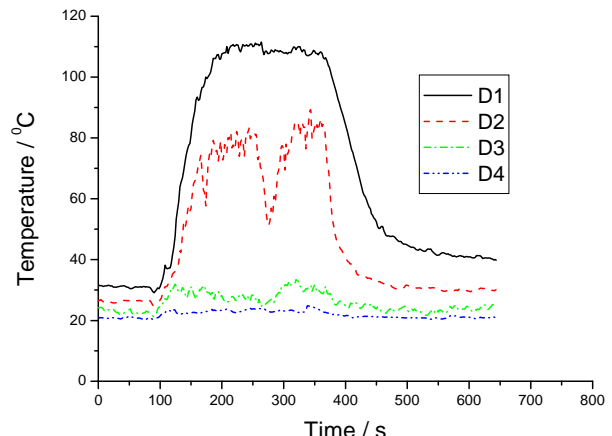

(b)

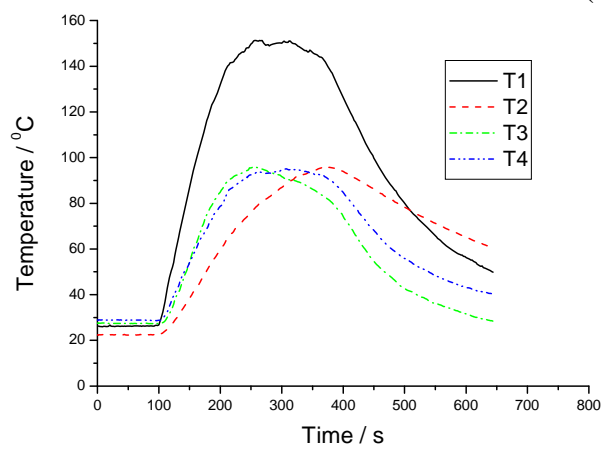

(c)

Fig. 8. Results for Test NP3: (a) vertical room temperature distributions; (b) vertical doorway temperature distributions; (c) temperatures at two layers of sprinklers.

For Test PC3, air temperature at above the cell ceiling reached a maximum of $240^{\circ} \mathrm{C}$ at 375 s after ignition with a short duration of temperature peak of $50 \mathrm{~s}$. The burning duration was $643 \mathrm{~s}$. Air temperature at the cell ceiling level increased at a slightly slower rate, with a maximum of $80^{\circ} \mathrm{C}$ which was lower than the maximum temperature $135^{\circ} \mathrm{C}$ below the cell ceiling. Temperatures at sprinkler point $\mathrm{T} 1, \mathrm{~T} 2, \mathrm{~T} 3$ and $\mathrm{T} 4$ reached a maximum of $255^{\circ} \mathrm{C}$ at $375 \mathrm{~s}$ after ignition, $175^{\circ} \mathrm{C}$ at $415 \mathrm{~s}$ after ignition, $80^{\circ} \mathrm{C}$ at $375 \mathrm{~s}$ after ignition and $70^{\circ} \mathrm{C}$ at $395 \mathrm{~s}$ after ignition, respectively. The burst of sensing bulbs of sprinklers were not seen for the same reason as that in Test PC2. Ignition of cell ceiling occurred at $171 \mathrm{~s}$.

For Test PC4, air temperature distribution was very similar to that of Test PC3 since all the experimental conditions were the same except the fire source was located in the opposite corner of the room. Air temperature above the cell ceiling reached a maximum of $225^{\circ} \mathrm{C}$ at $370 \mathrm{~s}$ after ignition with $647 \mathrm{~s}$ burning duration. The temperature at the cell ceiling level increased at a slightly slower rate, with a maximum of $95^{\circ} \mathrm{C}$ which was lower than the maximum temperature $138^{\circ} \mathrm{C}$ below the cell ceiling. Temperatures at sprinkler points T1, T2, T3 and $\mathrm{T} 4$ reached a maximum of $223^{\circ} \mathrm{C}$ at $382 \mathrm{~s}$ after ignition, $170^{\circ} \mathrm{C}$ at $398 \mathrm{~s}$ after ignition, $93{ }^{\circ} \mathrm{C}$ at $390 \mathrm{~s}$ after ignition and $82{ }^{\circ} \mathrm{C}$ at $400 \mathrm{~s}$ after ignition, respectively. The burst of sensing bulbs of sprinklers were not seen because of the same reason as that in Test PC2. Ignition of cell ceiling occurred.

\section{RESULTS WITHOUT PERFORATED CEILING}

For Test NP1, air temperatures inside the test room increased rapidly and reached a maximum of $147^{\circ} \mathrm{C}$ at $280 \mathrm{~s}$ after ignition and then maintained at its maximum for a period of $400 \mathrm{~s}$. The measured maximum temperature decreased as the measured height of the room decreased, ranging from $147^{\circ} \mathrm{C}$ at top level to $38^{\circ} \mathrm{C}$ at floor level with an upper layer temperature at about $101^{\circ} \mathrm{C}$. An exception was found where the measured temperature $\left(115^{\circ} \mathrm{C}\right)$ at $2.1 \mathrm{~m}$ above the floor (point M6) was dramatically higher than the measured points above M6. Temperatures at sprinkler points T1, T2, T3 and T4 reached a maximum of $163^{\circ} \mathrm{C}$ at $230 \mathrm{~s}$ after ignition, $112^{\circ} \mathrm{C}$ at $430 \mathrm{~s}$ after ignition, $90{ }^{\circ} \mathrm{C}$ at $180 \mathrm{~s}$ after ignition and $82{ }^{\circ} \mathrm{C}$ at $290 \mathrm{~s}$ after ignition, respectively. The sensing bulbs of sprinklers at $3 \mathrm{~m}$ above floor (i.e. mounting level of cell ceiling in Tests PC1 to PC4) burst at $89^{\circ} \mathrm{C}$ for point $\mathrm{T} 3$ and at $86^{\circ} \mathrm{C}$ for point $\mathrm{T} 4$, whereas bursting of the sprinkler-sensing bulbs for points $\mathrm{T} 1$ and $\mathrm{T} 2$ were not seen. 
For Test NP2, similar to Test NP1, air temperatures inside the test room increased rapidly and then reached a maximum of $276^{\circ} \mathrm{C}$ at $119 \mathrm{~s}$ after ignition and then maintained at its maximum for a period of $230 \mathrm{~s}$. The measured maximum temperature decreased as the measured height of the room decreased, ranging from $276^{\circ} \mathrm{C}$ at top level to $40^{\circ} \mathrm{C}$ at floor level with an upper layer temperature at about $170^{\circ} \mathrm{C}$. Again, the measured temperature at $2.1 \mathrm{~m}$ above floor (point M6) was $190^{\circ} \mathrm{C}$ which was higher than the measured points above M6. Temperatures at sprinkler point T1, T2, T3 and T4 reached a maximum of $327^{\circ} \mathrm{C}$ at $99 \mathrm{~s}$ after ignition, $202^{\circ} \mathrm{C}$ at $279 \mathrm{~s}$ after ignition, $167^{\circ} \mathrm{C}$ at $119 \mathrm{~s}$ after ignition and $167^{\circ} \mathrm{C}$ at $199 \mathrm{~s}$ after ignition, respectively. The sensing bulbs of sprinklers at $3 \mathrm{~m}$ above floor (i.e. mounting level of cell ceiling in Tests PC1 to PC4) burst at $124^{\circ} \mathrm{C}$ for point $\mathrm{T} 3$ and at $120^{\circ} \mathrm{C}$ for point $\mathrm{T} 4$, whereas bursting of the sprinkler-sensing bulbs for points $\mathrm{T} 1$ and $\mathrm{T} 2$ were not seen.

For Test NP3, air temperatures inside the test room also increased rapidly as in Tests NP1 and NP2 and reached a maximum of $130^{\circ} \mathrm{C}$ at $210 \mathrm{~s}$ after ignition and maintained at its maximum for a period of $160 \mathrm{~s}$. The measured maximum temperature decreased as the measured height of the room decreased, ranging from $130{ }^{\circ} \mathrm{C}$ at top level to $35^{\circ} \mathrm{C}$ at floor level with an upper layer temperature at about $107^{\circ} \mathrm{C}$. The measured temperature at $2.1 \mathrm{~m}$ above floor (point M6) was $117^{\circ} \mathrm{C}$ which was also higher than the measured points above M6. Temperatures at sprinkler points T1, T2, T3 and T4 reached a maximum of $150{ }^{\circ} \mathrm{C}$ at $150 \mathrm{~s}$ after ignition, $95^{\circ} \mathrm{C}$ at $270 \mathrm{~s}$ after ignition, $95^{\circ} \mathrm{C}$ at $150 \mathrm{~s}$ after ignition and $95^{\circ} \mathrm{C}$ at $150 \mathrm{~s}$ after ignition, respectively. Burst of the sprinkler-sensing bulbs were not seen.

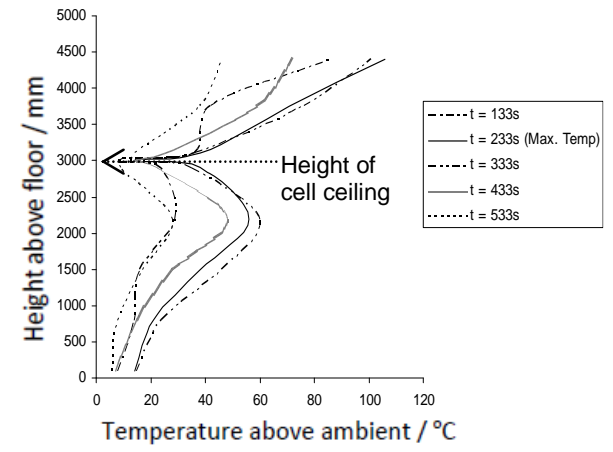

(a)

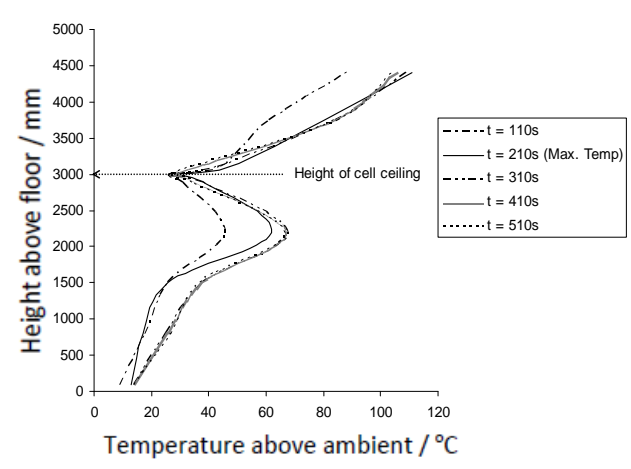

(b)

Fig. 9. Vertical temperatures for: (a) Test PC1; (b) Test PC2.

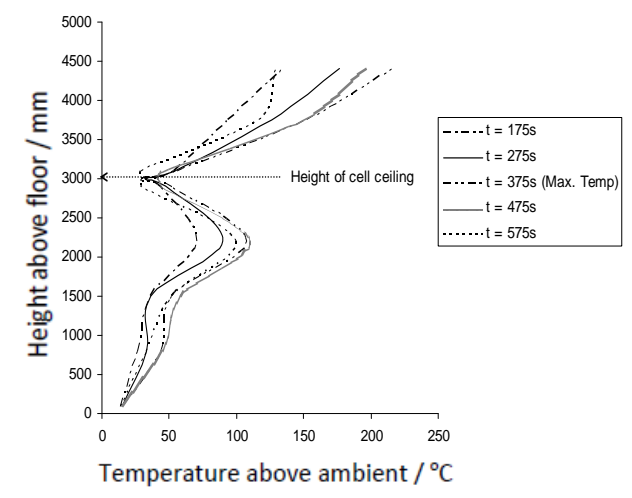

(a)

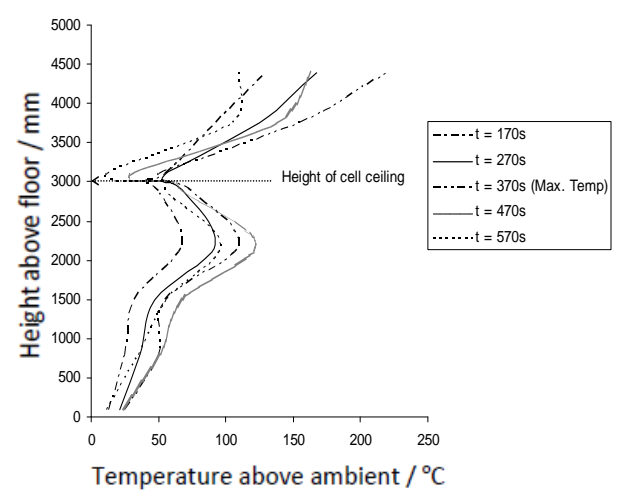

(b)

Fig. 10. Vertical temperatures for: (a) Test PC3; (b) Test PC4.

\section{EFFECT OF CEILING ON ROOM AIR TEMPERATURE}

For Tests PC1 and NP3, the presence of cell ceiling had no significant effect on the temperature layer near the solid ceiling. Both tests measured a maximum temperature of $130^{\circ} \mathrm{C}$ beneath the solid ceiling. As observed 
from Fig. 5, the presence of cell ceiling led to the formation of two spaces: the space inside the ceiling void and the space below the ceiling. In Test PC1 within the ceiling void, the temperature decreased as height decreased, ranging from $130^{\circ} \mathrm{C}$ to $39^{\circ} \mathrm{C}$ (points $\mathrm{M} 1$ to M4). For space below the ceiling, another hot layer was formed with a maximum temperature of $85^{\circ} \mathrm{C}$ at point $\mathrm{M} 6$ and $70^{\circ} \mathrm{C}$ at M7. In Test NP3, it presented a vertical temperature distribution, as in a single room, that temperature decreased as height decreased. The two spaces (ceilings) phenomenon was also found when comparing the results of Tests PC2 and NP1 as well as Tests PC3 and NP2. The two ceilings effect in Test PC2 led to two maximum ceiling layer temperatures of $135{ }^{\circ} \mathrm{C}$ at solid ceiling and $97^{\circ} \mathrm{C}$ at cell ceiling. While in Test PC3, the two maximum ceiling layers temperatures were $240^{\circ} \mathrm{C}$ at solid ceiling and $135^{\circ} \mathrm{C}$ at cell ceiling. Therefore, it was found that the cell ceiling does present a ceiling effect for accumulation of hot gas. Also, with the presence of the cell ceiling, the maximum temperature attained at the solid ceiling $\left(135^{\circ} \mathrm{C}\right.$ for Test PC2 and $240{ }^{\circ} \mathrm{C}$ for Test PC3) was slightly lower than that in the test with the absence of cell ceiling $\left(147^{\circ} \mathrm{C}\right.$ for Test NP1 and $276^{\circ} \mathrm{C}$ for Test PC3). This is due to the fact that the cell ceiling deflected the smoke plume from completely reaching the solid ceiling; rather, it split the smoke plume to form two layers with each layer temperature lower than that of the gas layer temperature wholly reaching the solid ceiling.

The vertical temperatures profiles (points M1 to M9) at the center of the room for Tests PC1 to PC4 were plotted in Fig. 9 and Fig. 10. Two temperature peaks, one at the solid ceiling ( $4.5 \mathrm{~m}$ from floor) and the other at about $1 \mathrm{~m}$ below the cell ceiling (i.e. $2.1 \mathrm{~m}$ from floor) were indicated in all these four tests. The temperature rises at the cell ceiling level (i.e. $3 \mathrm{~m}$ from floor) were only slightly higher than that at the lower level (e.g. $1 \mathrm{~m}$ above floor) of the room. The higher temperatures peak at the solid ceiling is due to the effect of ceiling jet, where the buoyant gases from the fire plume at the room corner reached the solid ceiling then moved horizontally until it reached the wall opposite to the fire source corner. The phenomena of gases layer descended uniformly across the whole solid ceiling area did not occur because of the ceiling jet was buoyant enough to continue its movement to find an opening. On the other hand, the second temperatures peak occurred at about $1 \mathrm{~m}$ below the cell ceiling. It is because that the cell ceiling obstructed the flow of the hot gases from the plume where a percentage of these gases did not reach of the solid ceiling but moved at a level below the cell ceiling. It then resulted that the cell ceiling had an insignificant temperature rise as it was sandwiched between the ceiling jet and the gases layer beneath the cell ceiling, both of which were at higher temperatures than that at the cell ceiling. Hence, air entrainments to both the hot ceiling jet and the less hot gases layer beneath the cell ceiling occurred within the ceiling void space.

The vertical temperatures profiles (points M1 to M9) for Tests NP1 to NP3 were plotted in Fig. 11 and Fig. 12 in which all had a shape showing a non-uniform vertical temperature rise. They had two peaks, one at the solid ceiling ( $4.5 \mathrm{~m}$ from floor) and the other at about $1 \mathrm{~m}$ below the cell ceiling (i.e. at $2.1 \mathrm{~m}$ from floor). It is believed that the temperatures peak occurred at about $2.1 \mathrm{~m}$ from floor may be due to the significant air entrainment effect from the door opening $(0.8 \mathrm{~m}$ wide, $2 \mathrm{~m}$ high), which had a dimension occupying at least one third of the room wall width $(2.4 \mathrm{~m})$ and wall height $(4.5 \mathrm{~m})$. From Fig. 7c, Fig. 7d and Fig. 8b, the vertical doorway temperatures at the doorway, e.g. point D1, for all the NP tests were higher than that of all the PC tests as shown in Fig. 5c, Fig. 5d, Fig. 6c and Fig. 6d. A larger vertical temperature different (points D1 to D4) was found at the doorway with the absence of cell ceiling which may cause larger quantity of cold air inflow to the room at the lower level of the door.

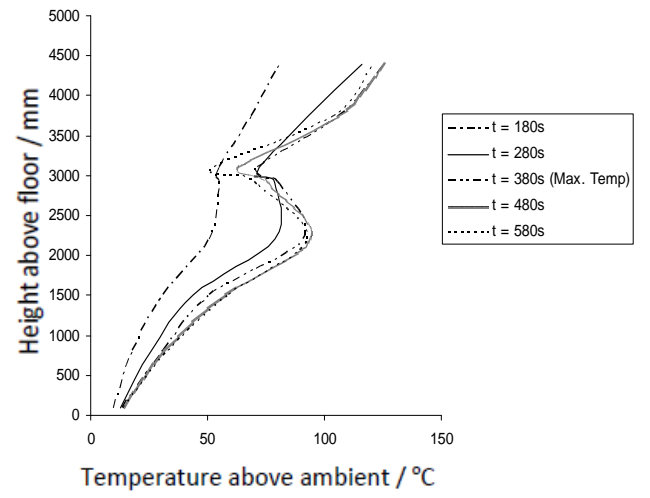

(a)

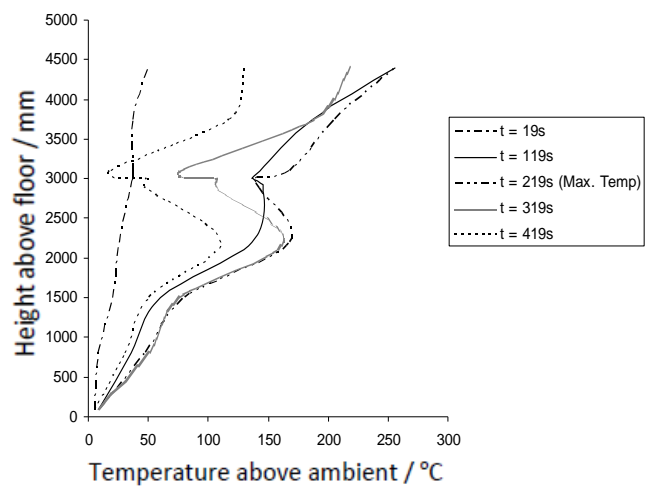

(b)

Fig. 11. Vertical temperatures for: (a) Tests NP1; (b) Test NP2. 


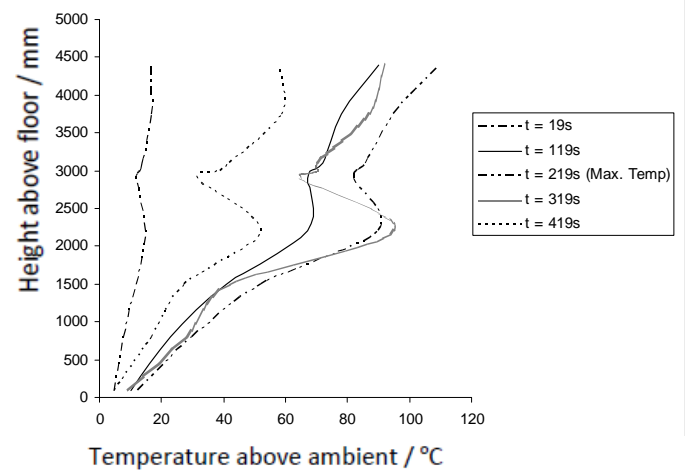

Fig. 12. Vertical temperatures for Test NP3.

\section{EFFECT OF FIRE TO ROOM AIR TEMPERATURE}

Burning duration and heat release rate of the pool fires were considered in the tests.

Tests PC1 and PC2 are tests with the same fire size of $250 \mathrm{~kW}$ but different burning durations (380 s and $739 \mathrm{~s}$ respectively). Tests NP1 and NP3 used the fire size of $250 \mathrm{~kW}$ with burning duration of $313 \mathrm{~s}$ and $675 \mathrm{~s}$, respectively. With the absence of cell ceiling, the longer the burning period, the higher the temperatures of the room (M1 in NP1 was $17^{\circ} \mathrm{C}$ higher than that in NP3, and M2 in NP1 was $10^{\circ} \mathrm{C}$ higher than that in NP3). This is because heat was supplied at a rate of $250 \mathrm{~kW}$ throughout the burning period. However, with the presence of cell ceiling and the longer duration of burning, the temperatures increased slower (M1 in PC2 was $5{ }^{\circ} \mathrm{C}$ higher than that in PC1, and M2 in PC2 was $8^{\circ} \mathrm{C}$ higher than that in PC1). It showed that the cell ceiling gave a lower overall temperature inside the room as the rising hot air plume deflected when it reached the cell ceiling.

Tests PC2 and PC3 (both with cell ceiling) are tests with fire size of $250 \mathrm{~kW}$ and $500 \mathrm{~kW}$, respectively. As expected, the measured maximum temperatures in Test PC3 were higher than that in Test PC2 with the differences of $105^{\circ} \mathrm{C}$ at point $\mathrm{M} 1,67^{\circ} \mathrm{C}$ at $\mathrm{M} 2,5^{\circ} \mathrm{C}$ at $\mathrm{M} 3,12^{\circ} \mathrm{C}$ at M4 and M5 and $38^{\circ} \mathrm{C}$ at M6. Tests NP1 and NP2 (both without cell ceiling) used the fire size of $250 \mathrm{~kW}$ and $500 \mathrm{~kW}$, respectively. The measured maximum temperatures in Test NP2 were higher than that in NP1 with the differences of $120^{\circ} \mathrm{C}$ at $\mathrm{M} 1,97^{\circ} \mathrm{C}$ at M2, $72^{\circ} \mathrm{C}$ at $\mathrm{M} 3$ and $\mathrm{M} 4,69^{\circ} \mathrm{C}$ at M5 and $75^{\circ} \mathrm{C}$ at M6. It can be observed that with the presence of the cell ceiling, the extent of temperature increase is relatively lower even if the fire size increased. This phenomenon as explained above is probably due to the existence of two spaces with cell ceiling presence, where the room centre temperature rise was dominantly driven by the temperature differential between the floor and the cell ceiling, a lower temperature differential between the floor and the solid ceiling under the situations with cell ceiling absence. This effect may lead to delayed operation of fire service installations with heat detection devices such as sprinklers.

\section{EFFECT OF CELL CEILING ON SPRINKLER ACTUATION}

Effects of perforated ceilings on liquid-in-bulb sprinkler heads were also studied. Activation times of the glass bulbs were recorded by observation with noise generated in glass breaking. Results are shown in Table 2.

In Test PC1, for fire size of $250 \mathrm{~kW}$, the sprinkler at the solid ceiling at point $\mathrm{T} 1$ and $\mathrm{T} 2$ burst at $71 \mathrm{~s}$ and $134 \mathrm{~s}$ after ignition, respectively, and the sprinklers at cell ceiling level did not burst. From the temperature curves in Figs. 5 to 7, temperatures at sprinkler point T2 were closer to the temperatures at sprinkler T1 when the cell ceiling was present. It is because the cell ceiling acted as a barrier to trap heat such that the air entrained into the hot gas layer was higher in temperature than the cases with the absence of the cell ceiling. Conversely, the hot gas layer temperatures at the solid ceiling were less uniform with the absence of a cell ceiling that temperatures at sprinkler point $\mathrm{T} 2$ were closer to the temperatures at points $\mathrm{T} 3$ and $\mathrm{T} 4$ as in Figs. 5b, 5d, 5f, 6b, 6d, 6f, 7b, 7d and 7f, due to the fact that temperatures decreased as distance from fire source increased. 
Whether the sprinkler heads at the cell ceiling level activated or not depends on the fire size and burning duration. From Table 2, sprinkler heads at cell ceiling level activated in Test NP1 (fire size of $250 \mathrm{~kW}$ and burning period of $675 \mathrm{~s}$ ) and Test NP2 (fire size of $500 \mathrm{~kW}$ and burning period of $416 \mathrm{~s}$ ). However, it did not actuate for a smaller fire size with a shorter burning duration as in Test PC1. It is also found from Fig. 9 and Fig. 10 that though the cell ceiling will contribute to accumulating smoke under the cell ceiling, the gas layer temperature at the cell ceiling $\left(<70^{\circ} \mathrm{C}\right)$ is not high enough to cause sprinklers $\mathrm{T} 3$ and T4 to activate.

\section{IGNITION OF CELL CEILING}

The test room is a room with dimensions $3.6 \mathrm{~m} \times 2.4 \mathrm{~m} \times 4.5 \mathrm{~m}(\mathrm{H})$ and the cell ceiling was made of wood. The cell ceiling was not ignited under the small test fire of $250 \mathrm{~kW}$ in Tests PC1 and PC2. However, the cell ceiling was ignited in Tests PC3 and PC4 with a bigger fire size of $500 \mathrm{~kW}$. Ignition occurred at the cell ceiling portion directly above the fire source at the room corner. Fig. 9 and Fig. 10 showed that room center air temperature at cell ceiling level in all PC tests were below $70^{\circ} \mathrm{C}$. As anticipated, the combustible false ceiling will be ignited under sufficient heat flux as demonstrated. In real situations, the presence of the perforated ceiling is expected to have effects on the air temperature distribution inside a room, which is a concern at early stages of a fire when the fire is still small in size. Such concerns will relate to the effective operation of the installed fire service installations such as sprinklers, which leads to the need to compare tests PC1 to PC4 and Tests NP1 to NP3. Other than its effect on air temperature distribution, if the wooden perforated ceiling is ignited either under sufficient large heat flux or after sufficient longer exposure to the heat source, fire hazards due to the heat contributed from the burning of the combustible ceiling will result.

As the tests covered in this paper were on studying air temperature distribution, separate tests are recommended to be carried out to study the fire hazards with the presence of wooden perforated ceiling in a room fire. Heat release rate is an important parameter to represent or reflect the degree of fire hazard with the presence of the wooden perforated ceiling. Hence, it is considered a subject for the subsequent tests to be measured. Timber perforated ceilings treated with fire retardant is another area of interest for fire tests, both with and without sprinklers.

\section{CONCLUSIONS}

False ceilings are an interior decoration item that changes its shape, dimensions and material to suit the modern trends. The effect of perforated suspended ceilings on proper functioning of the fire service installations should be considered in order to provide adequate fire safety. Very few studies [18,19] were reported on the understanding of room fires with perforated suspended ceilings.

In Hong Kong, other than some specific premises subject to licenses for operation (e.g. restaurants, catering areas, places of public entertainment), the fire performance of false ceilings (perforated or imperforated) for interior decoration have not been explicitly controlled. There is a need to understand in more detail the effect of perforated ceiling on the proper functioning of fire service installations. Experimental studies with two fire sizes of $250 \mathrm{~kW}$ and $500 \mathrm{~kW}$ were carried out to study the room temperature distributions with and without a cell ceiling as reported in this paper.

From the tests results, it is realized that the perforated ceiling would affect the room fire. Both the ceiling layer temperature and the maximum room temperature are affected. Effect on the room air temperature depends on the configuration of the perforated ceiling such as the degree of perforation, materials and mounting height. The orders of magnitude of the fire sources used in the tests would represent room temperature distribution in the early stage of an accidental fire. Information in the early stage of a fire is useful to study its effect on thermal activation of fire service installations. For a larger fire size, the combustible cell ceiling was ignited and burned. Further tests on the effect of heat contribution from a combustible cell ceiling are recommended.

\section{REFERENCES}

[1] AS 1530, Methods for Fire Tests on Building Materials, Components and Structures - Part 3: Simultaneous Determination of Ignitability, Flame Propagation, Heat Release and Smoke Release, Standards Australia, Australia, 1999.

[2] AS 1530, Methods for Fire Tests on Building Materials, Components and Structures - Part 2: Test for Flammability of Materials, Standards Australia, Australia, 1993. 
[3] BS 476, Fire Tests on Building Materials and Structures - Part 7: Method of Test to Determine the Classification of the Surface Spread of Flame of Products, British Standard Institution, London, UK 1997.

[4] BS EN 13501, Fire Classification of Construction Products and Building Elements - Part 1: Classification Using Data from Reaction to Fire Tests, British Standard Institution, London, UK 2002.

[5] ISO 9705, Fire Tests - Full-scale Room Test for Surface Products, International Organization for Standardization, Geneva, Switzerland, 1993.

[6] NFPA 286, Standard Methods of Fire Tests for Evaluating Contribution of Wall and Ceiling Interior Finish to Room Fire Growth, National Fire Protection Association, USA, 2006.

[7] Approved Document B, Fire Safety, Department of the Environment, London, UK, 2006.

[8] Building Code of Australia, Australia Building Code Board, Sydney, NSW, Australia, 2006.

[9] NFPA 101, Life Safety Code, National Fire Protection Association, Quincy, MA, USA, 2007.

[10] Code of Practice for Minimum Fire Service Installations and Equipment and Inspection, Testing and Maintenance of Installations and Equipment, Fire Services Department, Hong Kong, 2005.

[11] Code of Practice for Fire Resisting Construction, Buildings Department, Hong Kong, 1996.

[12] Babrauskas, V., (2002) The Role of Testing in Building Design, Fire Protection Engineering, 15: 3.

[13] Leung, C.W., and Chow, W.K., (2001) Review on Four Standard Test on Flame Spreading, International Journal on Engineering Performance-Based Fire Codes, 3(2): 67-86.

[14] Karlsson, B., North, G., and Gojkovic, D., (2002) Using Results from Performance-Based Test Methods for Material Flammability in Fire Safety Engineering Design, Journal of Fire Protection Engineering, 12(2): 93-108. http://dx.doi.org/10.1177/1042391502012002313

[15] Chow, W.K., Leung, C.W., Zou, G., Dong, H., and Gao, Y., (2004) Assessment of Fire Hazard in Timber Karaoke Music Boxes with Real-Scale Burning Tests, Journal of Applied Fire Science 12(2): 107-124. http://dx.doi.org/10.2190/EQRN-DJWD-8CYD-FLNR

[16] Babrauskas, V., (2002) Ignition of Wood: A Review of the State of the Art, Journal of Fire Protection Engineering 12(3): 163-189. http://dx.doi.org/10.1177/10423910260620482

[17] BS 7346, Components for Smoke and Heat Control Systems - Part 4: Functional Recommendations and Calculation Methods for Smoke and Heat Exhaust Ventilation Systems, Employing Steady-state Design Fires - Code of practice, British Standard Institution, London, UK, 2003.

[18] Marshall, N.R., Feng, S.Q., and Morgan, H.P., (1985) The Influence of a Perforated False Ceiling on the Performance of Smoke Ventilation Systems, Fire Safety Journal 8: 227-237. http://dx.doi.org/10.1016/0379-7112(85)90017-7

[19] Isaksson, S., Persson, B., and Tuovinen, H., “CFD-simulations of fire detection in a room with a perforated suspended ceiling, BRANDFORSK Project 628-951”, SP Report 1997:43, SP Swedish National Testing and Research Institute, Sweden, 1997.

[20] BS EN 12845, Fixed Fire Fighting Systems - Automatic Sprinkler Systems - Design, Installation and Maintenance, British Standard Institution, London, UK, 2004.

[21] Code of Practice for Means of Access for Firefighting and Rescue, Buildings Department, Hong Kong, 2004.

[22] Code of Practice for the Provision of Means of Escape in case of Fire, Buildings Department, Hong Kong, 1996. 